\title{
Analysis of Wound Dating by Gross and Histopathological Examination-A Postmortem Cross-Sectional Study
}

\author{
Vijay Kumar Ag ${ }^{1}$, Nithin Gowda ${ }^{2 *}$, M G Shivaramu ${ }^{3}$, Kumar $\mathbf{U}^{4}$ \\ ${ }^{I}$ Associate Professor, Department of Forensic Medicine \& Toxicology Adichunchanagiri Institute of Medical \\ Sciences, Adichunchanagiri University, B G Nagara, Nagamangala Taluk, Mandya, Karnataka State, India \\ ${ }^{2}$ Medical Student, Department of Forensic Medicine \& Toxicology Adichunchanagiri Institute of Medical \\ Sciences, Adichunchanagiri University, B G Nagara, Nagamangala Taluk, Mandya, Karnataka State, India \\ ${ }^{3}$ Professor \& Principal, Department of Forensic Medicine \& Toxicology Adichunchanagiri Institute of Medical \\ Sciences, Adichunchanagiri University, B G Nagara, Nagamangala Taluk, Mandya, Karnataka State, India \\ ${ }^{4}$ Professor \& Hod, Department of Forensic Medicine \& Toxicology Adichunchanagiri Institute of Medical \\ Sciences, Adichunchanagiri University, B G Nagara, Nagamangala Taluk, Mandya, Karnataka State, India
}

*Corresponding Author: Nithin gowda, Medical Student, Department of Forensic Medicine \& Toxicology Adichunchanagiri Institute of Medical Sciences, Adichunchanagiri University, B G Nagara, Nagamangala Taluk, Mandya, Karnataka State, India, Email: vijay.fmt@ rediffmail.com

\begin{abstract}
A wound/injury is defined as damage to any part of the body due to application of mechanical force. [1] The term wound describes the morphological and functional disruption of the continuity of a tissue structure. It is defined medico legally as "Any harm whatever illegally caused to any person in body, mind, reputation or property." Objectives of the study are to determine the age of injuries by gross and histopathological techniques and to correlate gross and histopathological changes in relation to time of injury. The study is conducted on the fatal cases subjected to medico-legal autopsy having well demarcated wounds. 50 abrasion cases were studied (Table 2), among which 16 cases showed bright red, 11 cases showed reddish scab, 8 cases showed brownish scab, 2 cases showed dark brown scab, 5 cases showed black scab, and in 6 cases the scab had fallen off at margins. In 4 cases, the scab had fallen off completely. Table 3 shows among 50 abrasions, 14 cases showed only hemorrhage and/or congestion of vessels. Margi nation of polymorphs was observed in 4 cases. This was seen earliest at 30 minutes and lasted up to 5 hours. By comparing gross changes with microscopic changes, among the injuries of 4 to 6 days in duration, 2 of 8 abrasions showed a dark brown scab, whereas by histological study, 5 of them showed granulation tissue, which confirmed the age of injury to be more than 4 days. Among the injuries of more than 2 weeks old, 3 of 9 abrasions showed a scab that has fallen off completely, whereas by histological study, 69 of the injuries showed dense collagen tissue with decreased cellular reaction, which confirms the injury as more than 2 weeks old. To conclude, though gross features of the injuries provides a rough estimate regarding their age, histological examination will confirm or gives a more accurate timing of their occurrence, thus aiding in administration of justice.
\end{abstract}

Keywords: Wound Dating, Gross Examination, Histopathological Examination

\section{INTRODUCTION}

A wound/injury is defined as damage to any part of the body due to application of mechanical force. [1]The term wound describes the morphological and functional disruption of the continuity of a tissue structure. It is defined medico legally as "Any harm whatever illegally caused to any person in body, mind, reputation or property."

Deaths resulting from blunt force trauma are one of the common cases encountered by the forensic pathologist and they occur in a variety of scenarios, like motor vehicle collisions, fall from height, etc. Hence wound examination is of prime importance in forensic pathology, police investigation and court of law, and it is desirable to establish a wound examination system to evaluate and record the nature of wound-either ante mortem or postmortem and to determine the age of the wound more accurately, so as to establish the relationship between time of infliction to the time of examination, which is medico legally significant. For age determination of injury, the knowledge of the timing of the repair processes 
is needed. Skin-wound healing is an orchestrated biological phenomena consisting of three sequential phases, inflammation, proliferation, and maturation.

Wound dating can be done by macroscopic/gross appearance, microscopic examination and by histochemistry techniques. Because of the variable results of the naked eye examination of the wounds it is important to study the injuries microscopically. Correlating the gross appearance with histological changes of wounds is still indispensable in spite of the sophisticated methods like histochemistry and immunehistochemistry for wound dating. [2]Hence this study of wound dating from macroscopic and microscopic level is taken up at our setup, to look into the accuracy of dating the wounds by comparing with the age determined by color changes and microscopic examination with that of the time of infliction of injury as informed by the police/FIR/hospital records.

\section{OBJECTIVES}

- To determine the age of injuries by gross and histopathological techniques.

- To correlate gross and histopathological changes in relation to time of injury.

\section{Methodology}

\subsection{Type of Study and Study Design}

Cross sectional study.

Duration: 2 months

\subsubsection{Study Population}

Cases subjected for medico-legal autopsy at Department of Forensic Medicine, Adichunchanagiri institute of medical sciences with the time of injury known.

\subsubsection{Sampling Method}

The study was conducted on the fatal cases subjected to medico-legal autopsy having well demarcated wounds. For the study a standard proforma was used to collect information regarding time of injury, time of death, associated co morbidities, and consent for tissue section after detailed interviews with investigating officer, relatives, friends or whoever witnessed the incident, and hospital Table1: Age and Sex distribution of the Cases records of the deceased. Standard autopsy protocol will be followed and relevant details of the injuries like position, size, color, shape was taken into consideration and age of injury was assessed depending on appearance. Then injuries was grouped into 7 different time intervals: - Time of Injuries between 0-4 hrs, 4$12 \mathrm{hrs}, 12-24 \mathrm{hrs}, 24-72 \mathrm{hrs}, 3-6$ days, 6-14 days and more than 2 weeks.

Then the representative areas of injury with adjacent normal appearing skin were sampled along with control sample taken from nearer tissue of injury and subjected for histopathological analysis. These tissues after processing was studied by using stains like $\mathrm{H} \&$ E stain and Van Gieson's stain (mixture of Picric Acid and Acid Fuchsin).

Sample size: 50 subjects.

\subsubsection{Inclusion Criteria}

- Cases where time of infliction of injury known.

\subsubsection{Exclusion Criteria}

- Cases where the wounds are infected.

- Cases who suffered with com or bidities like diabetes, peripheral vascular diseases, septicemia and thyroid disorders.

- Bodies in state of decomposition.

\subsubsection{Statistical Analysis}

Descriptive statistics using proportion, mean, standard deviation, percentage was used to describe the data. Chi-square test of proportion was used to compare proportions in the different groups. Level of significance was fixed at 5\%.

\subsubsection{Ethical Considerations}

Informed consent was obtained from relatives of deceased body and the ethical committee approval was obtained from Institutional Ethical Committee.

\section{Results}

In the present study totally 44 male and 6 female cases were selected and maximum number of cases belongs to age group of $21-40$ yeas( 25 cases).

\begin{tabular}{|l|c|c|c|}
\hline \multicolumn{1}{|c|}{ Age, $\mathbf{y}$} & Male, $\mathbf{n}(\boldsymbol{\%})$ & Female, (n \%) & Total, (n \%) \\
\hline $0-10$ & $1(100)$ & $0(0.0)$ & $1(100.0)$ \\
\hline $11-20$ & $3(100)$ & $0(0.0)$ & $3(100.0)$ \\
\hline $21-40$ & $23(92)$ & $2(8.0))$ & $25(100.0)$ \\
\hline
\end{tabular}


Analysis of Wound Dating by Gross and Histopathological Examination- A Postmortem Cross-Sectional Study

\begin{tabular}{|l|c|l|r|}
\hline $41-60$ & $14(82.35)$ & $3(17.64)$ & $17(100.0)$ \\
\hline$>60$ & $3(75)$ & $1(2.5)$ & $4(100.0)$ \\
\hline Total & $44(88)$ & $6(12)$ & $50(100.0)$ \\
\hline
\end{tabular}

\subsection{Gross Changes}

50 abrasion cases were studied (Table 2), among which 16 cases showed bright red, 11 cases showed reddish scab, 8 cases showed brownish scab, 2 cases showed dark brown scab, 5 cases showed black scab, and in 6 cases the scab had fallen off at margins. In 4 cases, the scab had fallen off completely.

Table2: Distribution of Abrasions by its Gross Changes According to Duration of Time Gross Changes

\begin{tabular}{|l|l|l|l|l|l|l|l|l|}
\hline $\begin{array}{l}\text { Age of } \\
\text { Injury }\end{array}$ & $\begin{array}{c}\text { Bright } \\
\text { Red,n(\%) }\end{array}$ & $\begin{array}{c}\text { Reddish } \\
\text { Scab,n(\%) }\end{array}$ & $\begin{array}{c}\text { Brownish } \\
\text { Scab, } \\
\mathbf{n}(\%)\end{array}$ & $\begin{array}{c}\text { Dark } \\
\text { Brown } \\
\text { Scab,n(\%) }\end{array}$ & $\begin{array}{c}\text { Black } \\
\text { Scab, } \\
\text { n(\%) }\end{array}$ & $\begin{array}{c}\text { Scab Margin } \\
\text { Falling } \\
\text { Off,n(\%) }\end{array}$ & $\begin{array}{c}\text { Scab Fallen Off } \\
\text { Completely, } \\
\text { n(\%) }\end{array}$ & $\begin{array}{c}\text { Total, } \\
\text { n(\%) }\end{array}$ \\
\hline $0-4 \mathrm{~h}$ & $14(87.5)$ & $0(0.0)$ & $0(0.0)$ & $0(0.0)$ & $0(0.0)$ & $0(0.0)$ & $0(0.0)$ & $14(28)$ \\
\hline $4-12 \mathrm{~h}$ & $2(12.5)$ & $3(27.2)$ & $0(0.0)$ & $0(0.0)$ & $0(0.0)$ & $0(0.0)$ & $0(0.0)$ & $5(10)$ \\
\hline $\begin{array}{l}12- \\
24 \mathrm{~h}\end{array}$ & $0(0.0)$ & $4(36.4)$ & $1(12.5)$ & $0(0.0)$ & $0(0.0)$ & $0(0.0)$ & $0(0.0)$ & $5(10)$ \\
\hline $\begin{array}{l}24- \\
72 \mathrm{~h}\end{array}$ & $0(0.0)$ & $4(36.4)$ & $5(62.5)$ & $1(50)$ & $0(0.0)$ & $0(0.0)$ & $0(0.0)$ & $10(30)$ \\
\hline $4-6 \mathrm{~d}$ & $0(0.0)$ & $0(0.0)$ & $2(25)$ & $1(50)$ & $1(20)$ & $1(16.7)$ & $0(0.0)$ & $5(10)$ \\
\hline $7-14 \mathrm{~d}$ & $0(0.0)$ & $0(0.0)$ & $0(0.0)$ & $0(0.0)$ & $3(60)$ & $3(50)$ & $1(50)$ & $7(14)$ \\
\hline$>2 \mathrm{wk}$ & $0(0.0)$ & $0(0.0)$ & $0(0.0)$ & $0(0.0)$ & $1(20)$ & $2(33.3)$ & $1(50)$ & $4(8)$ \\
\hline Total & $16(100)$ & $11(100)$ & $8(100)$ & $2(100)$ & $5(100)$ & $6(100)$ & $2(100)$ & $50(100)$ \\
\hline
\end{tabular}

\subsection{Microscopic Changes}

Table 3 shows among 50 abrasions, 14 cases showed only hemorrhage and/or congestion of vessels. Margi nation of polymorphs was observed in 4 cases. This was seen earliest at 30 minutes and lasted up to 5 hours. Early polymorphs infiltration was observed in 2

Table3: Distribution of Abrasions by its Microscopic Changes

\begin{tabular}{|c|c|c|c|c|c|c|c|c|c|c|c|c|}
\hline $\begin{array}{l}\text { Age of } \\
\text { Injury }\end{array}$ & $\begin{array}{l}\mathbf{0 , n} \\
(\%)\end{array}$ & $\begin{array}{l}1, n \\
(\%)\end{array}$ & $\begin{array}{l}2, n \\
(\%)\end{array}$ & $\begin{array}{l}3, n \\
(\%)\end{array}$ & $\begin{array}{l}4, n \\
(\%)\end{array}$ & $\begin{array}{l}5 . n \\
(\%)\end{array}$ & $\begin{array}{l}6, n \\
(\%)\end{array}$ & $\begin{array}{r}7, n \\
(\%)\end{array}$ & $\begin{array}{l}8, n \\
(\%)\end{array}$ & $\begin{array}{l}9, n \\
(\%)\end{array}$ & $10, \mathrm{n}(\%)$ & $\begin{array}{c}\text { Total,n } \\
(\%)\end{array}$ \\
\hline $0-4 \mathrm{~h}$ & $\begin{array}{l}11 \\
(78.6)\end{array}$ & $0(0.0)$ & $3(75)$ & $0(0.0)$ & $0(0.0)$ & $0(0.0)$ & $0(0.0)$ & $0(0.0)$ & $0(0.0)$ & $0(0.0)$ & $0(0.0)$ & $14(28)$ \\
\hline $4-12 h$ & 3(21.) & $0(0.0)$ & $1(25)$ & $1(50)$ & $0(0.0)$ & $0(0.0)$ & $0(0.0)$ & $0(0.0)$ & $0(0.0)$ & $0(0.0)$ & $0(0.0)$ & $5(10)$ \\
\hline $\begin{array}{l}12- \\
24 \mathrm{~h}\end{array}$ & $0(0.0)$ & $0(0.0)$ & $0(0.0)$ & $1(50)$ & $4(50)$ & $0(0.0)$ & $0(0.0)$ & $0(0.0)$ & $0(0.0)$ & $0(0.0)$ & $0(0.0)$ & $5(10)$ \\
\hline $\begin{array}{l}24- \\
72 \mathrm{~h}\end{array}$ & $0(0.0)$ & $0(0.0)$ & $0(0.0)$ & $0(0.0)$ & $4(50)$ & $3(75)$ & $1(50)$ & $2(28.6)$ & 0( & $0(0.0)$ & $(0.0)$ & 20) \\
\hline $4-6 d$ & $0(0.0)$ & $0(0.0)$ & $0(0.0)$ & $0(0.0)$ & $0(0.0)$ & $0(0.0)$ & $1(50)$ & $3(42.8)$ & $1(25)$ & $0(0.0)$ & $0(0.0)$ & $5(10)$ \\
\hline $7-14 d$ & $0(0.0)$ & $0(0.0)$ & $0(0.0)$ & $0(0.0)$ & $0(0.0)$ & $1(25)$ & $0(0.0)$ & 1(14.3) & $2(50)$ & $2(50)$ & $0(0.0)$ & $7(14)$ \\
\hline$>2 \mathrm{wk}$ & $0(0.0)$ & $0(0.0)$ & $0(0.0)$ & $0(0.0)$ & $0(0.0)$ & $0(0.0)$ & $0(0.0)$ & 1(14.3) & $1(25)$ & $2(50)$ & $1(100)$ & $4(8)$ \\
\hline Total & $14(100)$ & $0(100)$ & $4(100)$ & $2(100)$ & $8(100)$ & $4(100)$ & $2(100)$ & $7(100)$ & $4(100)$ & $4(100)$ & $1(100)$ & $50(100)$ \\
\hline
\end{tabular}

Microscopic Scoring

Table4: Correlation of Gross Changes with Microscopic Changes of Abrasion

\begin{tabular}{|c|c|c|c|c|c|c|c|c|c|c|c|c|}
\hline $\begin{array}{c}\text { Gross } \\
\text { changes }\end{array}$ & $\begin{array}{l}\mathbf{0 , n} \\
(\%)\end{array}$ & $\begin{array}{l}1, n \\
(\%)\end{array}$ & $\begin{array}{l}2, n \\
(\%)\end{array}$ & $\begin{array}{l}3, n \\
(\%)\end{array}$ & $\begin{array}{l}4, n \\
(\%)\end{array}$ & $\begin{array}{l}5 . n \\
(\%)\end{array}$ & $\begin{array}{l}6, n \\
(\%)\end{array}$ & $\begin{array}{l}7, n \\
(\%)\end{array}$ & $\begin{array}{l}8, n \\
(\%)\end{array}$ & $\begin{array}{l}9, n \\
(\%)\end{array}$ & $\begin{array}{l}10, n \\
(\%)\end{array}$ & $\begin{array}{c}\text { Total,n } \\
(\%)\end{array}$ \\
\hline Bright Red & $\begin{array}{l}12 \\
(75)\end{array}$ & $\begin{array}{l}0 \\
(0.0)\end{array}$ & $4(25)$ & $0(0.0)$ & $0(0.0)$ & $0(0.0)$ & $0(0.0)$ & $0(0.0)$ & $0(0.0)$ & $0(0.0)$ & $0(0.0)$ & $16(100)$ \\
\hline $\begin{array}{l}\text { Reddish } \\
\text { Scab }\end{array}$ & $\begin{array}{l}2(18 . \\
2)\end{array}$ & $0(0.0)$ & $0(0.0)$ & $2(18)$ & $5(45.4)$ & $1(9.1)$ & $0(0.0)$ & $1(9.1)$ & $0(0.0)$ & $0(0.0)$ & $0(0.0)$ & $11(100)$ \\
\hline $\begin{array}{l}\text { Brownish } \\
\text { Scab }\end{array}$ & $0(0.0)$ & $0(0.0)$ & $0(0.0)$ & $0(0.0)$ & $3(37.5)$ & $2(25)$ & $2(25)$ & $0(0.0)$ & $1(12.5)$ & $0(0.0)$ & $0(0.0)$ & $8(100)$ \\
\hline $\begin{array}{l}\text { Dark Brown } \\
\text { Scab }\end{array}$ & $0(0.0)$ & $0(0.0)$ & $0(0.0)$ & $0(0.0)$ & $0(0.0)$ & $1(50)$ & $0(0.0)$ & $1(50)$ & $0(0.0)$ & $0(0.0)$ & $0(0.0)$ & $2(100)$ \\
\hline Black Scab & $0(0.0)$ & $0(0.0)$ & $0(0.0)$ & $0(0.0)$ & $0(0.0)$ & $0(0.0)$ & $0(0.0)$ & $2(40)$ & $2(40)$ & $1(20)$ & $0(0.0)$ & $5(100)$ \\
\hline $\begin{array}{l}\text { Scab Margin } \\
\text { Falling Off }\end{array}$ & $0(0.0)$ & $0(0.0)$ & $0(0.0)$ & $0(0.0)$ & $0(0.0)$ & $0(0.0)$ & $0(0.0)$ & $2(33.3)$ & $1(16.7)$ & $2(33.3)$ & $\begin{array}{l}1 \\
(16.7)\end{array}$ & $6(100)$ \\
\hline
\end{tabular}


Analysis of Wound Dating by Gross and Histopathological Examination- A Postmortem Cross-Sectional Study

\begin{tabular}{|l|l|l|l|l|l|l|l|l|l|l|l|l|}
\hline $\begin{array}{l}\text { Scab Fallen } \\
\text { Off } \\
\text { Completely }\end{array}$ & $0(0.0)$ & $0(0.0)$ & $0(0.0)$ & $0(0.0)$ & $0(0.0)$ & $0(0.0)$ & $0(0.0)$ & $1(50)$ & $0(0.0)$ & $1(50)$ & $0(0.0)$ & $2(100)$ \\
\hline Total & $\begin{array}{l}14 \\
(28)\end{array}$ & $0(0.0)$ & $4(8)$ & $2(4)$ & $8(16)$ & $4(8)$ & $2(4)$ & $7(14)$ & $4(8)$ & $4(8)$ & $1(2)$ & $50(100)$ \\
\hline
\end{tabular}

Microscopic Scoring

\subsection{Correlation of Gross Changes with Microscopic Changes}

By comparing gross changes with microscopic changes, among the injuries of 4 to 6 days in duration, 2 of 8 abrasions showed a dark brown scab, whereas by histological study, 5 of them showed granulation tissue, which confirmed the age of injury to be more than 4 days. Among the injuries of more than 2 weeks old, 3 of 9 abrasions showed a scab that has fallen off completely, whereas by histological study, 69 of the injuries showed dense collagen tissue with decreased cellular reaction, which confirms the injury as more than 2 weeks old.

\section{DISCUSSION}

\subsection{Gross Changes}

50 abrasion cases were studied (Table 2), among which 16 cases showed bright red, 11 cases showed reddish scab, 8 cases showed brownish scab, 2 cases showed dark brown scab, 5 cases showed black scab, and in 6 cases the scab had fallen off at margins. In 4 cases, the scab had fallen off completely. Bright red color was observed in 16 cases; 14 of these injuries were 0 to 4 hours old. The 2 injuries were 4 to 12 hours old. Bright redness was observed earliest at 10 minutes and latest up to 5 hours. Reddish scab was noted in 11 cases, of which 4 injuries were 12 to 24 hours old. Brownish scab was noted in 8 cases, of which 5 were 24 to 72 hours old. The dark brown scab was noted in 2 cases, of which 1 injury (66.7\%) were 4 to 6 days old and the remaining 1 was 24 to 72 hours old. The earliest dark brown scab was noted at 44 hours, where the injury was situated over the face. The black scab was noted in 5 cases, of which 3 were 7 to 14 days old, 1 injury was 4 to 6 days old, and 2 were observed at more than 2 weeks. A scab fallen at the margin was seen in 6 injuries, of which 3 were of 7 to 14 days and the remaining 2 were more than 2 weeks old. The fall of scab was noted only after 6 days and was seen up to 15 days in a healthy individual where injury was located in the lower extremity (knee). In 2 cases, the scabs had fallen off completely, of which 1 was more than 2 weeks old, and in the remaining injury, the scab had fallen off at 11 days itself. In a healthy individual, it took up to 17 days for the scab to fall off completely. However, in a comatose the fall of scab (complete) was observed on the 27th day.

The Scoring for Microscopic Changes as Given in the Following Order

- Hemorrhage and/or congestion of vessels

- Edema formation

- Margi nation of polymorph cells

- Early infiltration of polymorph cells

- Predominant polymorph infiltration with poorly differentiated mononuclear cells

- Predominant mononuclear cell infiltration

- Appearance of fibroblast

- Granulation tissue with rich leukocyte infiltration and much fibroblasts

- Collagen tissue deposition Cellular reaction subsides; fibroblast are more active with increased collagen formation (regression phase of injury)

- Organized pustule formation in the presence of infection

\subsection{Microscopic Changes}

Table 3 shows among 50 abrasions, 14 cases showed only hemorrhage and/or congestion of vessels. Margi nation of polymorphs was observed in 4 cases. This was seen earliest at 30 minutes and lasted up to 5 hours. Early polymorphs infiltration was observed in 2 injuries. It was seen earliest at 6 hours. Predominant polymorph infiltration was observed in 8 injuries, of which 4 were 12 to 24 hours old and the remaining 4 were 24 to 72 hours old. It was noted earliest at 12 hours, and progressive increase was noted in the 24- to 72hour-old injuries. Mononuclear cell infiltration was first noted at 24 hours, and increased infiltration was observed in 3 injuries during 24 to 72 hours. It was noted that predominant mononuclear infiltration was between 35 and 50 hours in 5 injuries. The earliest regenerative change of epithelium was noted at 2 days. The active fibroblasts were evident only after 71 hours. The granulation tissue deposition was 
noted in 7 injuries, of which 3 were 4 to 6 days old, 2 were 24 to 72 hours old, and the remaining 2 injuries were 7 to 14 days old. The early granulation tissue (revascularization) was noted at 72 hours, and an increase in the deposition of granulation tissue was observed routinely by 4 to 6 days. The collagen tissue was noted in 4 injuries, of which 2 were 7 to 14 days old. The earliest collagen formation was seen at 96 hours and more commonly in 7- to 14-dayold injuries. The regression phase was noted in 4 injuries, of which 2 were more than 2 weeks old and the remaining injuries were 7 to 14 days old. The earliest regression phase was noted at 9 days and was more common in injuries of more than 2 weeks old. In 1 injury, the formation of organized pustule rich in polymorphs was noted during the period of 7 to 14 days and more than 2 weeks old.

\subsection{Correlation of Gross Changes with Microscopic Changes}

By comparing gross changes with microscopic changes, among the injuries of 4 to 6 days in duration, 2 of 8 abrasions showed a dark brown scab, whereas by histological study, 5 of them showed granulation tissue, which confirmed the age of injury to be more than 4 days. Among the injuries of more than 2 weeks old, 3 of 9 abrasions showed a scab that has fallen off completely, whereas by histological study, 69 of the injuries showed dense collagen tissue with decreased cellular reaction, which confirms the injury as more than 2 weeks old.

According to a study by vinay et.al., most of them were in the age group of 21 to 40 years $(50.5 \%)$, and men constituted more than three fourths $(88.1 \%)$ of the cases. Furthermore, $75.4 \%$ of the cases were due to road traffic injuries, and the remaining was due to railway injuries, fall from height, and so forth. The results concluded are as follows: on gross examination, bright red color was seen in injuries less than 5 hours old. The reddish scab was seen up to 68 hours. A brown scab was seen after 18 hours. A dark brown scab was observed only after 44 hours. A black scab was observed in the injuries more than 5 days old. It took at least 6 days for the scab to fall from the margin and 11 days to fall off completely.[7]

According to a study by Sharma A, Maximum number of cases is in the age group 21-30 years (40\%) followed by the age groups 31-40 years, $41-50$ years and $51-60$ years (13.34\% of cases in each group). The minimum number of cases is in the age groups of $<10$ years, $61-70$ years and $>70$ years (3.34\% of cases in each group) Redness is observed in $10 \mathrm{~min}$ and gradually changed into bluish discoloration in $7 \mathrm{hrs}$. The blue is observed up to 4th day and then the color becomes bluish black and is observed up to 6th day. From 6th day brown coloration of the contusion is observed which persists up to 7 th day. It is observed that the color of the contusion of 25 days duration resembles that of control. Swelling is observed in $10 \mathrm{~min}$ and stays up to 13 hrs. Polymorphic infiltration is first observed in 2 hrs. Significant increase in their count is observed at $19 \mathrm{hrs}$, which persists up to 48 hrs. A decrease in the number of polymorphs is observed second day onwards. Monocytic infiltration is first observed at $19 \mathrm{hrs}$. Moderate increase in their count is observed at 39 hrs. However, in one case moderate increase is observed in as early as $24 \mathrm{hrs}$. Significant increase in the monocyte count is observed at 46 hrs and persists up to fifth day and starts decreasing afterwards. Fibroblastic activity is observed at $19 \mathrm{hrs}$ and Collagen formation is observed after 3 days. [8]

In the study by Mohammed et.al., out of 128 cases, $44(34.4 \%)$ cases were $0-4 \mathrm{~h}$ old, 12 (9.4\%) cases were of duration $4-12 \mathrm{~h}, 11$ $(8.6 \%)$ cases were $12-24 \mathrm{~h}$ old, $21(16.4 \%)$ cases were 24-72 h old, 10 (7.8\%) cases were 4-6 days old, $19(14.8 \%)$ cases were of 7-14 days and the remaining $11(8.6 \%)$ cases were $>2$ weeks old. Gross changes in 101 abrasions were studied, amongst which 33 (32.7\%) showed bright red, $22(21.8 \%)$ reddish scab, $16(15.8 \%)$ brownish scab, $3(3.0 \%)$ dark brown scab, $10(9.9 \%)$ black scab and in $13(12.9 \%)$ injuries the scab was fallen off at margins. In $4(4.0 \%)$ injuries the scab had fallen off completely. Bright red colour was observed in 33 abrasions, 29 (87.9\%) of these injuries were $0-4 \mathrm{~h}$ old. The remaining 4 injuries were of 4-12 h old, more so they were in 4-5 $\mathrm{h}$ and were located in the less vascular areas of the extremities. No co morbidities were associated in any of these cases. Bright redness was observed earliest at $10 \mathrm{~min}$ and latest upto 5 h. Reddish scab was noted in 22 injuries, of which $8(36.4 \%)$ injuries were $12-24 \mathrm{~h}$ old. The remaining 14 were distributed equally $(31.8 \%$ each) in the duration 4-12 $\mathrm{h}$ and 24-72 $\mathrm{h}$. Reddish scab was observed earliest at $6 \mathrm{~h}$ and latest up to $68 \mathrm{~h}$. Brownish scab was noted in 16 injuries, of which $10(62.5 \%)$ injuries were of 24-72 h, the remaining 2 were $12-24 \mathrm{~h}$ old and 4 were 4-6 days old. The earliest brownish scab 
was noted at $18 \mathrm{~h}$ in 2 injuries, where both injuries were small size and the deceased were young who did not have co morbidities. The latest appearance of the brownish scab was at 132 hour (5.5 days). The dark brown scab was noted in 3 injuries, of which $2(66.7 \%)$ injuries were 4-6 days old and the remaining was 24-72 $\mathrm{h}$ old. The earliest dark brown scab was noted at $44 \mathrm{~h}$, where the injury was situated over face (more vascular area). The other 2 injuries were at $97 \mathrm{~h}$ and $144 \mathrm{~h}$, however their sizes $(2 \times 1$ and $5 \times 3 \mathrm{~cm}$ ) were small and deceased did not have any co morbidities. The black scab was noted in 10 injuries, of which 7 (70.0\%) injuries were 714 days old, and 1 injury was 4-6 days old and 2 were observed at $>2$ weeks. The black scab was seen only after 5 days and seen at 21 days in a deceased who had no co morbidities and was situated in the leg (less vascular area). In another case, black scab was noted at 35 days in an elderly male, who was poorly nourished, comatose, died of secondary infections consequent to head injury sustained and he had history of diabetes and hypertension. Scab fallen at the margin was seen in 13 injuries, of which 8 $(61.5 \%)$ injuries were of 7-14 days and remaining 4 were $>2$ weeks old. The fall of scab was noted only after 6 days and was seen up to 15 days in healthy individual where injury was located in the lower extremity (knee). In remaining 3 cases there was significant delay of fall of scab observed up to 45 days. All 3 of them were suffering from septicemia. In 4 injuries, the scabs had fallen off completely, of which $3(75.0 \%)$ injuries were $>2$ weeks old and in the remaining injury, the scab had fallen off at 11 days itself. In healthy individual it took up to 17 days for the scab to fall off completely. However in a comatose, who had co morbidities such as diabetes and septicemia, fall of scab (complete) was observed on 27th day. [9]

\section{CONCLuSion}

Determining the age of a wound is challenging in forensic field, but it can contribute to the reconstruction of crime scenes and lead to arrest of suspects. Forensic scholars have tended to focus on evaluating wound vitality and determining the time elapsed since the wound was sustained. The progress in forensic techniques, particularly high-throughput analyses, will enable the evaluation of materials at the cellular and molecular levels, as well as simultaneous assessment of multiple markers. To conclude, though gross features of the injuries provides a rough estimate regarding their age, histological examination will confirm or gives a more accurate timing of their occurrence, thus aiding in administration of justice.

\section{REFERENCES}

[1] Knight B, Saukko P. Pathology of wounds. Knights forensic pathology. $3^{\text {rd }}$ ed. London: Arnold Publishers; 2004, p. 136, 166-169.

[2] Raekallio J, Timing of wounds--an introductory review: Ann Acad Med Singapore. 1984 Jan; 13(1):77-84.

[3] Sharma A, Dikshit PC, Aggrawal A, Mandal AK. A post mortem study of histopathological findings to determine the age of abrasion and laceration. Journal of forensic medicine and toxicology: jan-june 2010; vol 27(1), p. 43-46.

[4] Janssen W, Forster S. Forensic histopathology, Berlin: Springer-verlag; 1984, p.97.

[5] Dimaio VJ, Dimaio D. Blunt trauma wounds. Forensic pathology. $2^{\text {nd }}$ ed. Florida: CRC press; 2001, p. 94-98, 101-104.

[6] Nandy A. Mechanical injuries. Principles of forensic medicine and Toxicology. $3^{\text {rd }}$ ed. New central book agency; p.342, 352.

[7] Javaregowda Vinay, A Study on Postmortem Wound Dating by Gross and Histopathological Examination of Abrasions. Am J Forensic Med Pathol. 2017 Jun; 38(2): 167-173.

[8] Sharma A. A Histopathological Study to Determine the Age of Contusion. Journal of Punjab Academy of Forensic Medicine \& Toxicology. 2010; 10:17-19.

[9] Mohammed Abdul Mujeeb Siddiqui. Histopathological Study of Blunt Force Injuries in Relation to Time since Death. IJCMR. 2016; 3(9):2780-3

Citation: Vijay Kumar Ag, Nithin Gowda, M G Shivaramu, Kumar U. Analysis of Wound Dating by Gross and Histopathological Examination-A Postmortem Cross-Sectional Study. ARC Journal of Forensic Science. 2020 5(1):1-6. http://dx.doi.org/10.20431/2456-0049. 0501001.

Copyright: (0) 2020 Authors. This is an open-access article distributed under the terms of the Creative Commons Attribution License, which permits unrestricted use, distribution, and reproduction in any medium, provided the original author and source are credited. 